\title{
iCETL
}

International Conference on Research in Education, Teaching and Learning

Paris, France| November 2-4, 2018

\section{Teaching Mathematics through Images: The Importance of Visuality in University Coursebooks}

\author{
Nárcisz Kulcsár \\ Department of Mathematics and Computational Sciences, Széchenyi István University
}

\begin{abstract}
Visuality intertwines all areas of life, our brain needs to process a wide range of visual stimuli. Physiological processes in the brain (myelination process) cause that adolescence and young adults learn typically differently. Therefore to help them better comprehend difficult subjects, visual aids need to be utilized.

These reasons lead us to pay more attention in higher education on visuality. The preferable ration between text and images in the textbooks should be between 30 and $50 \%$ but the question is that what shows the reality. Miguel de Guzman, a Spanish mathematician dealt with visuality in mathematics. He distinguished four different types of visualization in mathematics due to the strength of relation between the object and its visual mapping.

Based on the theoretical background some mathematics coursebooks for engineers were investigated that students use currently or used in our or in other universities in Hungary. Some comparisons were made from a visual point of view based on Guzman's theory and on other visual aspects. These findings contributed to develop a new mathematics coursebook in our university in which visual elements got more attention.
\end{abstract}

\section{Introduction}

We are part of a specific iconic revolution in which the dominancy of the written language expiry and the importance of the visuality increases. Globalization catalyses the visual language with its universality and internationality to become a world language. The dramatic rise of the role of visual culture has impact on education culture as well.

Text just can't compete with images. Our brain works differently in both cases, but in the case of analysing a text brain accomplish more advanced process. At birth, a baby understands images, forms and shapes earlier than is able to understand what words mean. We understand images instantly while in contrast we have to work to process text.

In fact, the brain processes images faster than it does text, which contribute to orient in the world much easier. It is useful to know visual marketing's statistics better, because as one of the goals of marketing is to create interest, which is also the task of education. Visual marketing statistics say that $80-90 \%$ of the information sent to the brain is visual, and $93 \%$ of all human communication is visual. Our eyes are capable of registering 36.000 visual messages per hour. $40 \%$ of all nerve fibers connected to the brain are linked to the retina [1]. These data underlay the importance of the images and direct our attention to use visual aid in education. 


\section{iC亘TL}

International Conference on Research in Education, Teaching and Learning

Paris, France| November 2-4, 2018

\section{Areas of the Brain Affected}

In order to produce an image that we see with our eyes, various areas of the brain work together in a multitude of ways.

The most processes take place in the visual cortex of the brain, which can be found in the occipital lobe of the brain. During visual impact, brain goes through three main processes: visual recognition, categorization, and encoding (learning).

The first step for the brain is to recognize the acquired new visual information. Brain areas involved in recognition are the inferior temporal cortex (crucial for the visual identification of objects), the superior parietal cortex (crucial for the visual location of objects), and the cerebellum. During tasks of recognition, there is increased activation in the left inferior temporal cortex and decreased activation in the right superior parietal cortex [2].

In the next step the brain categorize the information, i.e. create new groups or assimilate them in already existed groups. Several prefrontal regions are activated in categorization, including bilateral orbitofrontal and lateral prefrontal cortex [3].

The final process with encoding leads to learning. More areas of the brain such as the frontal lobe, the right extrastriate cortex, theneocortex, and the neostriatum are responsible for this process [4]. One region, the limbic-diencephalic has a big role to transform perceptions into memories [5].

\section{Brain Maturation into Young Adulthood}

Gray matter in the brain is responsible for generating nerve impulses that process brain information, and white matter is responsible for transmitting brain information between lobes and out through the spinal cord. Nerve impulses are transmitted by myelin, a fatty material that grows around a cell. White matter has a myelin sheath (a collection of myelin) while gray matter doesn't, which efficiently allows neural impulses to move swiftly along the fiber [6].

Myelination is the process of coating the axon of each neuron with a fatty coating called myelin, which protects the neuron and helps it conduct signals more efficiently. Myelination begins in the brain stem and cerebellum before birth, but it is not completed in the frontal cortex until late in adolescence [7].

The myelin sheath isn't fully formed until around ages 24-26 [8]. Therefore myelination affects the learning process, i.e. adolescents and young adults learn differently. Visual aids contribute to help them to comprehend better the difficult subjects. These reasons lead us to pay more attention on visuality in higher education.

\section{Visualization as a Pedagogical Method}

In teaching of mathematics, we distinguish two kinds of perspectives: abstraction and demonstration, of which the latter builds on sensory perception and observation. Researches show that visualization enhances the effectiveness of education, contributes to a deeper understanding of knowledge and more permanent memorization, especially if it involves more senses [9]. Visualization is just one of the 


\section{iCETL}

International Conference on Research in Education, Teaching and Learning

Paris, France| November 2-4, 2018

possibilities of demonstration with the involvement of vision. Interpretation of diagrams and illustrations does not occur spontaneously, but requires instructional work from teacher.

Much of the visualization can still be done by hand, paper, pencil, chalk, and board, but the possibilities offered by the technology open up a new space for the instructors to deliver the content in a meaningful way. Technique can also help to visualize content which is unavailable manually. All these technological advances, computer graphics play a great part in rediscovering visualization.

\section{Visuality in Textbooks}

Textbook researches say that there are many standards for the textbooks. Based on international researches we can list 3 areas: standards of disciplines, didactical standards, preferred topics and perspectives. Standards of disciplines contains content aspects based on multiperspective and multidimensional thinking. Didactical standards focus on age-specific psychological nature, visuality, real-life thinking, differentiation, harmony of different kind of methods. Preferred topics and perspectives are peace, human rights, respect of nature and environment, respect of other nations, religions, and human cultural heritage [10].

Reference [10] goes into more details of the standards of visuality. It mentions that, visual rhetoric of the textbook should pay attention to the change of students' visual culture. Images must not be a tool for communicating stereotypes and prejudice. The preferable ration between text and images on a page in the textbooks should be between 30 and $50 \%$ but the question is that what shows the reality.

Another important aspect is that, images should not only decorate, but help to understand the topic, deepen the knowledge, reveal relationships, and last but not least enhance interest and motivation.

\section{Visualization in Mathematics}

The basic ideas of mathematics are from the observation of the simplest situations of life, from concrete visualizable situations. When describing certain properties of nature (distance, size, order) or changes, a new language was born, the language of mathematics. When translating into the language of mathematics -called mathematization-, first we are looking for a connection between world phenomena, then we find general contexts and finally we treat them in a symbolic way to discover additional contexts and to reutilize them. Among the branches of mathematics, geometry has the most direct relation to visuality with the visualization of the planar and spatial objects. Rudolf Arnheim in his book entitled Visual Thinking (in the chapter Thinking with Pure Shapes) deals with mathematics education. According to the author, not only the "self-evident geometry", but also arithmetic and algebra have perceptual basis: the calculations are preceded by the perceptual grasp of groups and the numbers are perceptual entities, visual and often tactile and auditory [11]. It would be incorrect idea to think that everything can be visualized in mathematics, even 


\section{iC亘TL}

International Conference on Research in Education, Teaching and Learning

Paris, France| November 2-4, 2018

though it is intertwining its entire system. The perceptual world extends to 3 dimensions, while mathematics moves in higher dimensions as well.

\section{Different Type of Visualization in Mathematics}

Miguel de Guzman, a Spanish mathematician dealt with visuality in mathematics. He distinguished 4 different types of visualization in mathematics due to the strength of relation between the object and its visual mapping.

Guzman brings some visual examples for the different kind of visualization but his examples are mainly related to theorems and its proof and problems with the solutions [12].

\subsection{Isomorphic visualization}

In mathematics two structures are isomorphic if the form of the two structures is the same, only the elements are otherwise named. This kind of visualization is used when a strong relation is between visualization and the maths problem. The concrete visualization gives direction to solve an abstract problem. The most of the maths visualization is part of this category. Mathematicians accept this type of visualization the most with no hesitation. We have to know that visualization is dependent from traditions and various kinds of conventions. It is true ,an image is worth a thousand words", but it presupposes that, we know a specific sign system and we can decode and understand it. See Fig. 1.
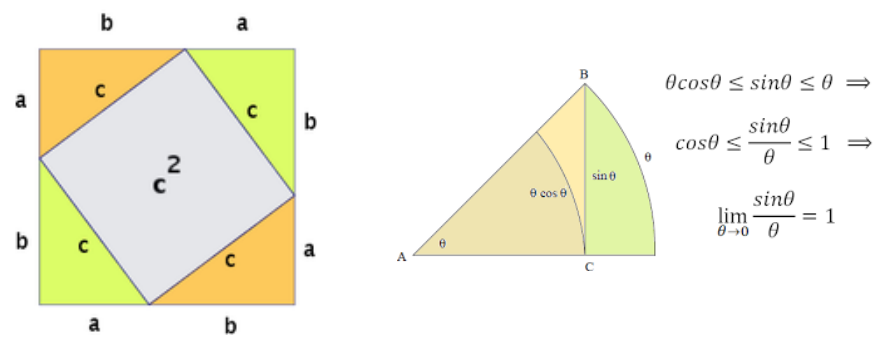

Fig. 1. Examples for isomorphic visualization

\subsection{Homeomorphic visualization}

In mathematics two structures are homomorphic if the elements of the two structures are the same, but differ in form. In this visualization the relationship of different kind of abstract objects is visualized which helps to understand guesses and proofs. Here you cannot find direct relation between the visual signs and mathematical content. Therefore the visualization process is quite subjective and sometimes it is not easy to communicate. See Fig 2. 


\section{iCETL}

International Conference on Research in Education, Teaching and Learning

Paris, France| November 2-4, 2018
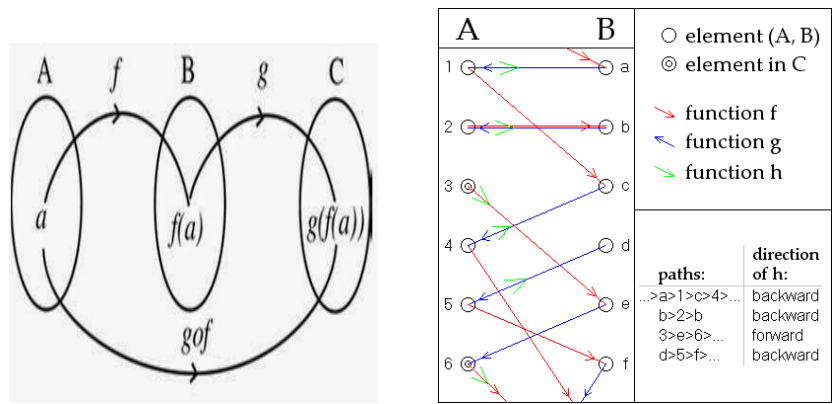

Fig. 2. Examples for homeomorphic visualization

\subsection{Analogical visualization}

This type of visualization is the most complex. Here we mentally substitute the object we are working with another that relate between themselves in an analogous way whose is perhaps easier to handle. This kind of visualization was one of the usual discovery methods used by Archimedes in his famous letter -The Method- to Eratostenes. See Fig. 3.

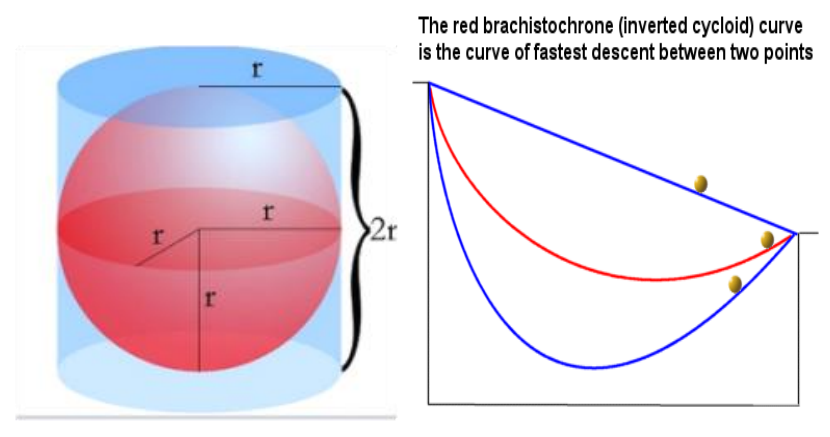

Fig. 3. Examples for analogical visualization

\subsection{Diagrammatic visualization}

In this kind of visualization our mental objects and their mutual relationships are represented by diagrams. Diagrams become in some cases of generalized use, but in many cases they are of a very personal, individual use and cannot be shared easily with others. The tree diagram we use in probability or Venn-diagram in set theory or Hasse-diagram in number theory can be found in this category. See Fig. 4. 


\section{iCETL}

International Conference on Research in Education, Teaching and Learning

Paris, France| November 2-4, 2018
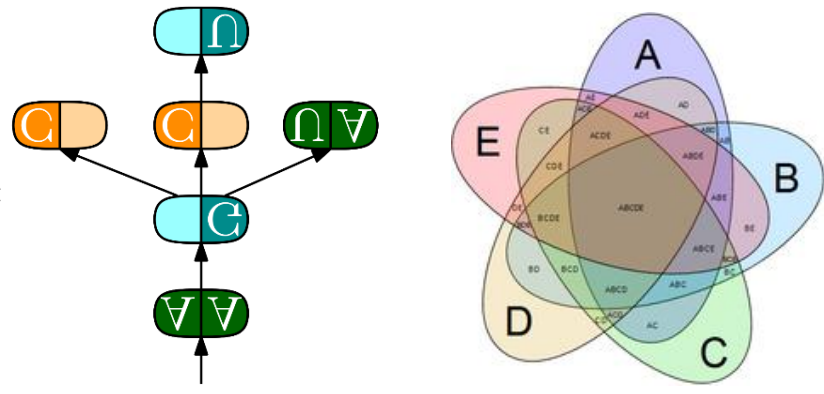

Fig. 4. Examples for diagrammatic visualization

Be aware of that, Guzman states that this categorization is neither exhausted nor clear in many cases and we can find many cases which cannot be enclosed in any of the types.

\section{Different Type of Visualization in Mathematics}

I made a comparative analysis of different mathematics coursebooks which were written for technical university students. These books were written for Hungarian students by Hungarian teachers from different universities. I chose those books which main topic was calculus because it is a basic course with similar contents for all engineers in all universities in Hungary. Another reason for choosing these books was that, calculus can be visualized the easiest after the topic of geometry. The mathematical relationships do not change over time, and the mathematical bases taught to engineers have not changed significantly in the last decades. Only a few topics have been added or removed from engineering education. That is why I have involved older and newer books into my examinations as well. The chosen books are available for our students in the library of Széchenyi István University [13]-[21].

I was interested in that what kind of similarities and differences are between these mathematics coursebooks and what kind of characteristics they have in the aspect of visuality. I investigated ten books in 15 different aspects: number of pages, number of pictures, number of pictures/page, pictoriality (how pictures, diagrams, graphics fit to the text, type and ratio of pictorial and nonpictorial contents), signs which support understanding, graphics and typography, colors (raising awareness, motivation, harmony), positive side of visuality in total, negative side of visuality in total, isomorphic visualization, homeomorphic visualization, analogical visualization and diagrammatic visualization.

Table I shows the number of pages, number of pictures, and which type of visualization appear in the book. The sign of $\checkmark$ means that kind of visualization appears in the book. The sign of $\mathrm{X}$ means that kind of visualization does not appear in the book at all. Table I contains the title of the books [13]-[22] in English language. Looking at the ratio of text and illustrations, none of the books reach the minimum 


\section{iCETL}

International Conference on Research in Education, Teaching and Learning

Paris, France| November 2-4, 2018

$30 \%$ ratio, the textual parts dominate. Except for [15] most of the pages of the chosen books do not contain any figures. In [13] most of the images are collected on some pages far from the referred explanations. I did not find any images which had decorative function, each image had a specific role in comprehension, reception, or processing of the knowledge. This research confirms that the most widely used visualization method is isomorphic visualization, while there are hardly any examples of homeomorphic and analogical visualization. In my opinion, the more types of visualization we use, the more help we give to understand a phenomenon. Variety of types of visualization implies a diversity of explanations.

Reference [15] and [16] have an outstanding number of images compared to the number of pages. The dispersion of the figures is very variable in all books, there are topics in [13], [16], [19], and [20] where there are not any pictures in the theoretical explanations at all. This is not accidental, because as the themes become more and more abstract, the number of figures decreases dramatically and finally disappears. In [15] images present not only mathematical context, but technical contents as well. In the other nine coursebooks, images visualize only mathematical content. Reference [18] does not explain any theoretical background, it lists only mathematical examples. In the second part of the book we can find the solutions of the tasks without any explanations. Except for 2 pictures, all the other images can be found among the solutions. The situation is similar with [21], where except for 4 figures, images take place among the solutions. After examining the images in exercises in the other books as well, I could see that the pictures are mostly related to the solutions, there are rare those questions which interpret the figures.

If we look at the typography of the books, we see that each book is printed in black and white. One of the reasons for this could be the cost-effectiveness of printing, and on the other hand the color of the figures would not necessarily contribute to a deeper understanding in these cases. Except for [19], in all books figures are numbered and referenced in the text. It is not confusing in [19], there is no numbering, because the text is interrupted by the images at the right place, and it is clear all the times where they belong. There are only three books which cover present functions or numerical symbols [14], [17], [20], on the cover of the other books there are not any mathematical signs which could indicate the subject, content or topic of the book from outside. The function on the cover of [14] can be found in the book, but the origin of the graph on [17] is not the book. The mathematical formula on the cover of [20] can be found in the book also.

Overall, it can be stated that, the figures are excellent additions to understand the mathematical theorems and to solve the examples.

Based on the findings above, I and my colleagues paid more attention to the visual aspects in our new coursebook [22]. Although the proportion of images does not reach the desired $30 \%$, we have increased their number compared to the other books. We 


\section{iCETL}

\section{International Conference on Research in Education, Teaching and Learning}

Paris, France| November 2-4, 2018

used all types of visualization (based on Guzman's theory) in order to make our explanations diverse. We considered it important to use explanatory figures in every topic. Among exercises not only those kinds of tasks were presented which solutions need a graph, but also those where we need to read some information about the graph, so the image must be interpreted. Before printing we have little influence on book pagination, typography, cover, and colors, because our book is part of a series and the book must meet some certain conditions. We have to be aware that, not only us but the publisher should also think that visuality and visual aids for students are important.

Table 1 Technical Higher Education Mathematics Coursebooks from Visual Aspects

\begin{tabular}{|c|c|c|c|c|c|c|c|c|c|c|}
\hline & 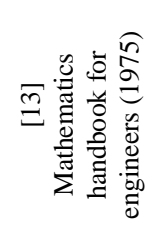 & 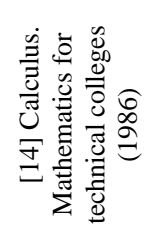 & 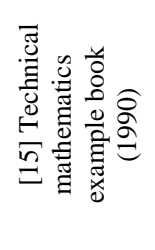 & 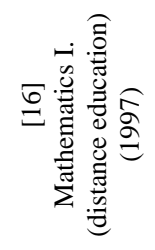 & 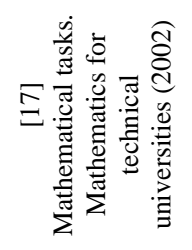 & 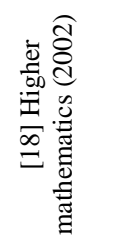 & 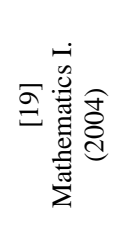 & 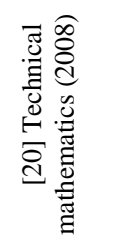 & 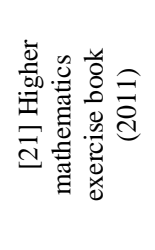 & 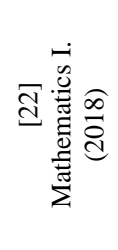 \\
\hline $\begin{array}{l}\text { Number of } \\
\text { pages }\end{array}$ & 995 & 472 & 96 & 148 & 398 & 706 & 441 & 155 & 555 & 417 \\
\hline $\begin{array}{l}\text { Number of } \\
\text { illustrations }\end{array}$ & 187 & 140 & 71 & 119 & 63 & 242 & 66 & 24 & 24 & 247 \\
\hline $\begin{array}{l}\text { Isomorphic } \\
\text { visualization }\end{array}$ & $\checkmark$ & $\checkmark$ & $\checkmark$ & $\checkmark$ & $\checkmark$ & $\checkmark$ & $\checkmark$ & $\checkmark$ & $\checkmark$ & $\checkmark$ \\
\hline $\begin{array}{l}\text { Homeomorphic } \\
\text { visualization }\end{array}$ & $\checkmark$ & $\checkmark$ & $\mathrm{X}$ & $\checkmark$ & $\mathrm{X}$ & $\checkmark$ & $\mathrm{X}$ & $\mathrm{X}$ & $\mathrm{x}$ & $\checkmark$ \\
\hline $\begin{array}{c}\text { Analogical } \\
\text { visualization }\end{array}$ & $\checkmark$ & $\mathrm{X}$ & $\checkmark$ & $\mathrm{X}$ & $\mathrm{X}$ & $\checkmark$ & $\mathrm{X}$ & $\mathrm{X}$ & $\mathrm{x}$ & $\checkmark$ \\
\hline $\begin{array}{l}\text { Diagrammatic } \\
\text { visualization }\end{array}$ & $\checkmark$ & $\checkmark$ & $\checkmark$ & $\checkmark$ & $\checkmark$ & $\checkmark$ & $\mathrm{X}$ & $\checkmark$ & $\checkmark$ & $\checkmark$ \\
\hline
\end{tabular}

\section{References}

1. E. Jensen: Brain Based Learning: The New Paradigm of Teaching, CA: Corwin Press, CA: Thousand Oaks, 2008

2. M. Mishkin, L. G. Ungerleider, K. A. Macko: "Object vision and spatial vision: two cortical pathways," Trends in Neuroscinces, vol. 6, pp. 414-417, 1983

3. R. Vogels, Gy. Sary, P. Dupont, G. A. Orban: "Human Brain Regions Involved in Visual Categorization," Neuroimage, vol. 16, no. 2, pp. 401-414, 2002

4. L. Nyberg, A.R. McIntosh, R. Cabeza, R. Habib, S. Houle, E. Tulving: 'General and specific brain regions involved in encoding and retrieval of events: what, where, and 


\section{iC亘TL}

International Conference on Research in Education, Teaching and Learning

Paris, France| November 2-4, 2018

when,' in Proc. of the national Academy of Sciences of the United States of America, vol. 93, no. 20, pp. 11280-11285, Oct. 1996

5. Squire, L.: 'Declarative and Nondeclarative Memory: Multiple Brain Systems Supporting Learning and Memory,' in: Memory Systems, D. L. Schacter, Endel Tulving, Eds. Cambridge, MA: MIT Press, pp. 203-231, 1994

6. Visual Learning. https://en.wikipedia.org/wiki/Visual_learning

7. R.Peterson: Working Memory and Processing Speed Among Pediatric Brain Tumor Patients Treated with Photon or Proton Beam Radiation Therapy, Indiana University, 2017, dissertation.

8. P. Wolfe: Brain Matters: Translating the Research to Classroom Practice, Association for Supervision and Curriculum Development, 2001

9. G. Ambrus, K. Munkácsy, É. Szeredi, É. Vásárhelyi, G. Wintsche: 'Matematika módszertani példatár,' http://tankonyvtar.ttk.bme.hu/pdf/160.pdf

10. Á. Dárdai: 'Az összehasonlító tankönyvkutatás nemzetközi tapasztalatai', Education, vol. 9, no. 3, pp. 498-408, 2000

11. K. Nyíri: 'Images in Conservative Education', in: How to Do Things with Pictures, series VISUAL LEARNING, vol. 3, A. Benedek, K. Nyíri, Eds. Frankfurt/M.: Peter Lang, pp. 191-207, 2013

12. M. Guzman: 'The Role of Visualization in the Teaching and Learning of Mathematical Analysis', in Proc. of the International Conference on the Teaching of Mathematics (at the Undergraduate Level), Hersonissos, Crete, Greece, 2002

13. G. A. Korn, T. M. Korn: Matematikai kézikönyv müszakiaknak, Budapest, Müszaki Könyvkiadó, 1975

14. J. Kovács, G. Takács, M. Takács: Matematika a müszaki föiskolák számára: Analízis (fóiskolai tankönyv), Budapest, Nemzeti Tankönyvkiadó, 1986

15. L. Huszty: Müszaki matematikai példatár, Miskolci Egyetem Gépészmérnöki Kar, 1990

16. I. V. Kutiné, R. Horváth: Matematika 1. (távoktatás), Széchenyi István Főiskola, 1997

17. Obádovics J. Gy., Szarka Z.: Felsőbb matematika, Budapest, Scolar Kiadó, 2002

18. V. Scharnitzky: Ed., Matematika a müszaki föiskolák számára: Matematikai feladatok: föiskolai segédkönyv, Budapest, Nemzeti Tankönyvkiadó, 2002

19. G. Horváth, A. Lukács: Matematika 1, Györ, Universitas-Győr Kht., 2004

20. D. Gaál: Müszaki matematika, Budapest, Müszaki Tankönyvkiadó, 2008

21. J. Gy. Obádovics: Felsőbb matematikai feladatgyüjtemény, Budapest, Scolar Kiadó, 2011

22. G. Horváth, N. Kulcsár, A. Lukács, E. Molnárka-Miletics: Matematika 1, 2018, unpublished. 